\title{
A partir de onde fala Foucault?
}

[Where does Foucault speaks from?]

\section{Otávio Ventura®}

Resumo: Proponho neste trabalho uma reflexão sobre o lugar de fala de Michel Foucault, dado que ele mesmo negava a filosofia, as ciências sociais ou a história como seus territórios. Sugiro que tais negações podem estar ligadas à dissociação que Foucault fazia entre linguagem e verdade. Foucault entendia que a natureza infinita da linguagem apagaria qualquer sistema de referências. $O$ simples ato de falar sobre as coisas franquearia, portanto, uma distância, que seria, em si mesma, ficção. O objetivo aqui é salientar uma maneira possível de compreender Foucault, não a partir de eventuais posicionamentos fixos, mas em seus incessantes e propositais deslocamentos.

Palavras-chave: Foucault, linguagem, verdade.

Abstract: This work proposes a reflection about Michel Foucault's place of speech, since he denied philosophy, social science or history as his territories. I suggest that such denials might be connected to the dissociation made by Foucault between language and truth. Foucault believed that the infinite nature of language would erase any system of reference. To speak about things would produce, therefore, a distance, which would be, itself, fiction. The goal here is to emphasize a possible way to understand Foucault, not from eventual fixed positionings, but in his incessant and purposeful shifts.

Keywords: Foucault, language, truth.

Introdução

Admirado e defendido por alguns, criticado e rejeitado por outros, muitas são as formas de recepção e reação ao pensamento de Michel Foucault, figura indubitavelmente polêmica que sabia combinar uma atitude particularmente provocadora com uma escrita enigmática e sedutora.
O estilo de Foucault parecia ser o de trilhar caminhos não meramente alternativos aos que se desenvolviam em sua época, mas muitas vezes diametralmente opostos, mesmo possuindo laços institucionais tão tradicionais quanto um título de doutorado pela Université Paris-Sorbonne ou uma cadeira de professor no Collège de France. De forma implí-

\footnotetext{
${ }^{*}$ Doutorando em Ciência Política pela Universidade de Brasília (UnB), e membro da carreira federal de planejamento e orçamento. E-mail: otavium@gmail.com. / ORCID: https://orcid.org/0000-0002-3243-4730.
} 
cita ou explícita, em maior ou menor grau, Foucault se esquivoul 1 , dentre outras formas de saber, das ciências humanas, da epistemologia, da historiografia, da fenomenologia, do humanismo e do estruturalismo.

Se Foucault diz que não fala a partir de nenhum desses lugares, então a partir de onde ele fala? Qual é o lugar e o estatuto de sua fala? Que forma de saber é essa? É uma nova forma de filosofia? De história? De ciência? Quais são as suas condições de possibilidade? Que poder é exercido a partir dela? Há vontade de verdade?

Este artigo nasceu para pensar sobre estas perguntas. Propõe-se aqui que antes de se aceitar ou rejeitar a obra de Foucault, talvez seja preciso refletir sobre qual é o estatuto de sua fala. Defendese que as noções de linguagem e de verdade em Foucault talvez possam ajudar a esclarecer alguns aspectos sobre isso. E sugere-se, por fim, que essas noções talvez tenham inspirado em Foucault certas práticas de si.

Além desta breve introdução, 0 trabalho está organizado em outras três partes. A próxima seção defende a pertinência de se perguntar de onde fala Foucault. A seção seguinte apresenta uma leitura possível sobre as noções de linguagem e de verdade em Foucault. A última seção conclui o trabalho explorando algumas práticas que Foucault faz de si mesmo, com ênfase em seus incessantes deslocamentos.

\section{A pertinência de se perguntar de onde fala Foucault}

Foucault falou sobre a loucura, a clínica, a ciência, a prisão, a sexualidade, o poder, o sujeito, e sobre muitos outros temas que coincidem em alguma medida com objetos comuns às ciências humanas. Além disso, empregou métodos que de certa maneira parecem guardar alguma similitude com o ofício dos historiadores. E situou suas análises de forma a valorizar ou rejeitar certas tradições filosóficas.

Tudo isso contribui para que Foucault seja, de forma mais ou menos automática, considerado como um cientista, como um historiador ou como um filósofo, ou como alguém que transita no interior dessas formas de saber, ainda que esteja situado em suas fronteiras. E boa parte da recepção da obra de Foucault parte dessas presunções.

No trecho abaixo, Foucault ex-

\footnotetext{
${ }^{1}$ Estes afastamentos estão justificados de forma fragmentada em grande parte de sua obra, mas uma síntese destas justificativas pode ser encontrada em Foucault (2014b). 
pressa seu choque ao ser primeiramente comparado com o sociólogo canadense Erving Goffman, e em seguida criticado por não fazer sociologia à altura dele:

Uma coisa me chocou nos sumários que foram feitos dos meus livros nos Estados Unidos, em particular no que se escreveu sobre o livro que dediquei às prisões. Disseram que eu procurava fazer a mesma coisa que Erving Goffman em sua obra sobre os asilos, a mesma coisa, mas não tão bem. (FOUCAULT, 2006, p. 319)

O historiador italiano Carlo Ginzburg relata em entrevista um episódio onde ouviu de seu colega de profissão, o inglês Edward Thompson, a acusação de que Foucault seria um charlatão:

Lembro-me de estar uma vez num café de Paris conversando com E. P. Thompson e começamos a falar sobre Foucault. Foi quando Thompson disse algo que pensei ter ouvido errado: 'Foucault é um charlatão!'. Pedi que repetisse, tal minha surpresa, e era isso mesmo. (GINZBURG, 1999)

Ginzburg afirma ainda que Foucault deveria ser tratado apenas como uma nota de rodapé a $\mathrm{Ni}$ etzsche:
[...] diria que Foucault é um autor extremamente superestimado, pois em grande parte ele nada mais é do que uma nota de rodapé a Nietzsche. (GINZBURG, 1999)

Cientista-social-medíocre, historiador-charlatão, filósofo-nota-derodapé, essas são algumas imagens caricatas de Foucault que surgem a partir de certas críticas dirigidas a ele fundadas na premissa de que ele fracassou como alguém que supostamente tentava falar do interior das ciências humanas, da história ou da filosofia. No entanto, há críticas mais bem elaboradas.

No prefácio original ${ }^{2}$ de $A$ história da loucura (1961), Foucault afirma que não desejava escrever a história da linguagem psiquiátrica, mas arqueologia do silêncio

\footnotetext{
${ }^{2}$ Em 1972, Foucault escreveu um novo prefácio para A história da Loucura.
} 
da loucura:

A linguagem da psiquiatria, que é o monólogo da razão sobre a loucura, só se pode estabelecer sobre tal silêncio. Minha intenção não era escrever a história dessa linguagem, mas, em vez disso, elaborar a arqueologia desse silêncio. (FOUCAULT, 1961, p. IV)

Aparentemente, Foucault não queria dar voz a essa linguagem da razão, a psiquiatria, mas sim ao silêncio da loucura. Jacques Derrida proferiu em 1963 uma conferência destinada a criticar este livro de Foucault. Um dos pontos levantados por Derrida se refere à suspeita de que talvez seja impossível que essa arqueologia de Foucault não fosse também uma obra de razão:

[...] a arqueologia, ainda que do silêncio, não é uma lógica, ou seja, uma linguagem organizada, um projeto, uma ordem, uma frase, uma sintaxe, uma 'obra'? (DERRIDA, 2009,
Em seguida, Derrida coloca a questão do lugar de fala de Foucault, perguntando-se qual seria o estatuto desta coisa chamada arqueologia:

[...] quais serão a fonte e o estatuto da linguagem dessa arqueologia, dessa linguagem que deve ser entendida por uma razão que não é a razão clássica? Qual é a responsabilidade histórica dessa lógica da arqueologia? Onde situála? (DERRIDA, 2009, p. 49)

Um pouco mais à frente na conferência, Derrida situa Foucault como alguém que quer escrever história a partir de um método estruturalista 3

Mas me pergunto se, quanto se trata de história (e Foucault quer escrever uma história), um estruturalismo estrito é possível [...]. (DERRIDA, 2009, p. 61)

\footnotetext{
${ }^{3}$ No prefácio de $A$ arqueologia do saber, Foucault tenta esclarecer, talvez em uma resposta direta a Derrida, que o que ele fez em A história da loucura "não se trata de transferir para o domínio da história, e singularmente da história dos conhecimentos, um método estruturalista que foi testado em outros campos de análise." (FOUCAULT, 2008, p. 17).
} 
O argumento de Derrida pode ser visto como uma forma de usar Foucault contra ele mesmo. Se Foucault procurou situar a linguagem da psiquiatria no lado da razão e se afastar dela ao escrever a arqueologia da loucura, Derrida tentou mostrar, ou pelo menos levantar dúvidas, sobre como essa arqueologia de Foucault não seria também uma obra de razão, tanto quanto a razão psiquiátrica denunciada por ele mesmo.

Jürgen Habermas usa uma estratégia parecida. Em seu Discurso filosófico da modernidade (2000), Habermas dedica dois capítulos exclusivamente a Foucault, um para descrever sua obra, outro para criticá-la. Um ponto de crítica elaborado por Habermas se refere à noção de poder-saber de Foucault, baseada na premissa, expressa em $A$ ordem do discurso (2014) e transcrita abaixo, de que a norma dos discursos científicos não seria, como se acredita, a verdade, mas sim o poder, na forma de vontade de verdade:

[...] na vontade de dizer esse discurso verdadeiro, o que está em jogo, senão o desejo e o poder? O discurso verdadeiro, que a necessidade de sua forma liberta do desejo e liberta do poder, não pode reconhecer a vontade de ver- dade que o atravessa; e a vontade de verdade, essa que se impõe a nos há bastante tempo, é tal que a verdade que ela quer não pode deixar de mascarála. (FOUCAULT, 2014, p. 19)

Habermas, em uma operação semelhante à de Derrida, busca aplicar Foucault contra Foucault, chamando atenção para o fato de que se a premissa da vontade de verdade estivesse correta e fosse aplicada à obra de Foucault, então as pretensões de verdade de Foucault estariam comprometidas, assim como suas críticas às ciências humanas, pois teriam que ser consideradas não como verdade, mas como vontade de verdade:

Por outro lado, essa hipótese fundamental da teoria do poder e autoreferencial; se é correta, precisa destruir igualmente a base de verdade das pesquisas por ela inspiradas. Mas se a pretensão de verdade que o próprio Foucault vincula a sua genealogia do saber fosse, de fato, ilusória e se esgotasse nos efeitos que essa teoria poderia desencadear no círculo de seus 
adeptos, então toda atividade de um desmascaramento crítico das ciências humanas perderia seu alcance. (HABERMAS, 2000, p. 391)

Habermas, em seguida, enquadra Foucault como alguém que quer praticar uma ciência:

[...] Foucault exerce a historiografia genealógica com a intenção séria de realizar urna ciência superior às falidas ciências humanas. (HABERMAS, 2000, p. 391)

Pierre Bourdieu também usa Foucault contra Foucault. Em um capítulo de Meditações Pascalianas (2001) dedicado aos fundamentos históricos da razão, Bourdieu retoma e critica tanto Habermas quanto Foucault, rejeitando ambos os projetos:

Não temos tampouco de escolher entre os dois termos da nova alternativa hoje simbolizada pelos nomes de Haber- mas e Foucault, eles próprios sendo heróis epônimos de dois 'movimentos', ditos 'moderno' e 'pósmoderno' [...]. (BOURDIEU, 2001, p. 130)

Classificando Foucault como um pós-moderno, como já havia feito Habermas 4 , as severas críticas de Bourdieu descrevem Foucault como um filósofo que tenta fazer uma desconstrução que não lembra de desconstruir a si própria:

[...] 'desconstrução' que esquece de 'desconstruir' o 'desconstrutor'. Em movimento incessante, apreendendo e inapreensível, o filósofo sem eira nem beira, atopos, pretende escapar, conforme a metáfora nietzschiana da dança, a qualquer localização, a qualquer ponto de vista fixo de espectador imóvel e a qualquer perspectiva objetivista, afirmando-se capaz de adotar, em face do texto submetido à 'desconstrução', um número infinito de pontos de vista inaces-

\footnotetext{
${ }^{4}$ Habermas afirma que as análises de Foucault seriam fundadas em uma "retórica pós-moderna" (HABERMAS, 2010, p. 395), situando-o próximo do pensamento de Lyotard, autor do polêmico A condição pós-moderna (2009). Foucault, por seu turno, não aceitava o rótulo de pós-moderno, até porque rejeitava como confusa e sem sentido a própria ideia de pós-modernidade, conforme relatou em 1983 em uma entrevista (FOUCAULT, 2005, pp. 322-323). 
síveis tanto ao autor como ao crítico; sempre altaneiro e novidadeiro, apanhador inagarrável que apenas aparentemente renunciou ao sonho de transcendência, sonho no jogo de nunca se dar por achado, notadamente em relação às ciências sociais, que ele absorve para melhor desafiá-las, 'ultrapassá-las' e refutálas, está sempre seguro de colocar em questão os questionamentos mais radicais e, quando não sobra mais nada para a filosofia, pronto a demonstrar que ninguém consegue desconstruir melhor a filosofia do que o próprio filósofo." (BOURDIEU, 2001, pp. 130-131)

Retomando os três exemplos, então, Derrida faz suas críticas situando Foucault como alguém que quer escrever história, Habermas faz suas críticas falando de um Foucault que quer fazer ciência, e Bourdieu fala de Foucault como alguém que pratica uma filosofia sem eira nem beira.

De certa maneira, parece razoável supor que as críticas desses autores, embora bem elaboradas, talvez reafirmem, em alguma medida, as imagens caricatas de
Foucault, aquelas do cientistasocial-medíocre, do historiadorcharlatão ou do filósofo-nota-derodapé, mesmo que algumas dessas críticas não deixem de problematizar a questão do lugar de fala de Foucault.

No entanto, assumir para Foucault um lugar de fala específico e criticá-lo como se ele falasse de tal lugar talvez seja uma operação arriscada. É relativamente claro que Foucault se relaciona com a filosofia, com as ciências humanas e com a história quase o tempo todo, o que muitas vezes pode sugerir uma filiação de Foucault a esta ou aquela disciplina, corrente, teoria ou área de conhecimento.

Mas o próprio Foucault não situa sua obra nem na filosofia, nem nas ciências humanas, nem na história. Em uma entrevista de 1975, Foucault fala sobre um lugar fora da filosofia:

Liberar-se a si mesmo da filosofia implica necessariamente uma similar falta de consideração. Não se pode sair dela fincando-se dentro dela, refinando-a tanto quanto possível, dando voltas ao redor dela com o próprio discurso. Não. Conseguese isso, opondo-se a ela, com uma espécie de es- 
panto e alegria, uma espécie de incompreensível crise de riso que no final se torna entendimento, ou que em todo caso, destrói. Sim, destrói antes de levar ao entendimento. (FOUCAULT, 1986, p. 4)

Em As palavras e as coisas (2010a), deixa clara a sua posição em relação às ciências do homem:

A todos os que pretendem ainda falar do homem, de seu reino ou de sua liberação, a todos os que formulam ainda questões sobre o que é o homem em sua essência, a todos os que pretendem partir dele para ter acesso à verdade, a todos os que, em contrapartida, reconduzem todo conhecimento às verdades do próprio homem, a todos os que não querem formalizar sem antropologizar, que não querem mitologizar sem desmistificar, que não querem pensar sem imediatamente pensar que é o homem quem pensa, a todas essas formas de reflexão canhestras e distorcidas, só se pode opor um riso filosófico - isto é, de certo modo, silencioso. (FOUCAULT, 2010a, p. 473)

E mesmo quando Foucault descreve sua arqueologia como uma prática histórico-filosófica, faz questão de frisar que isso nada tem a ver com filosofia da história ou história da filosofia:

[...] certa prática que se chamaria históricofilosófica, que não tem nada a ver com a filosofia da história e a história da filosofia [...] (FOUCAULT, 1990, p. 11)

De forma ainda mais direta, trechos de duas entrevistas concedidas por ele em 1978 e 1979 mostram o quanto ele foi taxativo ao se negar $\sqrt{5}$ como filósofo, cientista social ou historiador:
Sou um experimentador, $\mathrm{e}$ não um teórico. Chamo de teórico aquele que cons- trói um sistema global, seja de dedução, seja de

\footnotetext{
${ }^{5}$ No início de sua carreira ele era menos restritivo em relação a esses rótulos, aceitando um ou outro, a depender de como eram definidos. Em uma entrevista de 1967 (FOUCAULT, 2014b), por exemplo, ele aceitou os rótulos de filósofo, historiador e etnólogo, mas apenas depois de definir o que eram essas coisas para ele. Com o passar dos anos, isso vai sumindo das entrevistas, até chegar na negação total de qualquer desses nomes.
} 
análise, e o aplica de maneira uniforme a campos diferentes. Não é o meu caso. (FOUCAULT, 2010b, p. 290)

Não me considero um filósofo. O que faço não é nem uma maneira de fazer filosofia nem de sugerir aos outros que não o façam. (FOUCAULT, 2010b, p. 291)

Não sou um pesquisador em ciências sociais. (FOUCAULT, 2006, p. 319)

Não sou um artista e não sou um cientista. (FOUCAULT, 2006, p. 319)

Muito simplesmente, não sou historiador. (FOUCAULT, 2006, p. 321)

Com base nestas negações de Foucault, é razoável supor que o assumir como filósofo, cientista social ou historiador, e criticá-lo a partir dessas posições, é, no mínimo, problemático. Parece ser pertinente questionar a partir de onde fala Foucault, portanto.

\section{Linguagem e verdade em Fou- cault}

Há em Foucault uma profunda suspeita sobre a linguagem. Em uma conferência de 1975, Foucault atribui a Nietzsche, Freud e
Marx o mérito pela introdução de uma nova hermenêutica que interpreta não mais palavras ou coisas, mas que interpreta interpretações:

Isto já se observa em Marx, que não interpreta a história das relações de produção, mas interpreta uma relação que se dá já como uma interpretação, porque se oferece como natural. Inclusive Freud, não interpreta símbolos, mas interpretações. (FOUCAULT, 1997, p. 23)

Desta mesma forma $\mathrm{Ni}^{-}$ etzsche apodera-se das interpretações que são já prisioneiras umas das outras. Não há para Nietzsche um significado original. [...]. É também neste sentido no qual Nietzsche diz que as palavras foram sempre inventadas pelas classes superiores; não indicam um significado, impõem uma interpretação. (FOUCAULT, 1997, pp. 22-23)

A partir disso, Foucault alerta para o perigo da linguagem, já que os símbolos não devem mais ser tomados como meros significantes a serem interpretados: 
O símbolo, ao adquirir

2014b, p. 34)

esta nova função de encobrimento da interpretação, perdeu a sua simplicidade do significante [...]. (FOUCAULT, 1997, p. 24)

Os símbolos são interpretações que tratam de justificar-se, e não o inverso. (FOUCAULT, 1997, p. 24)

Seria preciso suspeitar da linguagem, portanto. E essa suspeita de Foucault sobre a linguagem não é apenas uma questão marginal que talvez ajude a explicar lateralmente o seu lugar de fala. Ao contrário, Foucault deu grande importância à linguagem em sua obra, relacionando-a inclusive ao tema próprio da razão:

[...] pela análise das próprias condições de nossa racionalidade, eu me questiono sobre nossa linguagem, minha linguagem, da qual analiso o modo sobre o qual ela pôde surgir. (FOUCAULT,

\footnotetext{
6 "Consideremos a oitava categoria, a das pedras. Wilkins as divide em comuns (sílex, cascalho, ardósia), de preço módico (mármore, âmbar, coral), preciosas (pérola, opala), transparentes (ametista, safira) e insolúveis (hulha, greda e arsênico). Quase tão alarmante quanto a oitava é a nona categoria. Esta nos revela que os metais podem ser imperfeitos (cinabre, azougue), artificiais (bronze, latão), recrementícios (limalha, ferrugem) e naturais (ouro, estanho, cobre)." (BORGES, 2007a, pp. 123-124)

7 "Em suas remotas páginas está escrito que os animais se dividem em a) pertencentes ao Imperador, b) embalsamados, c) amestrados, d) leitões, e) sereias, f) fabulosos, g) cachorros soltos, h) incluídos nessa classificação, i) que se agitam feito loucos, j) inumeráveis, k) desenhados com um pincel finíssimo de pêlo de camelo, 1) et cetera, m) que acabam de quebrar o jarrão, n) que de longe parecem moscas." (BORGES, 2007a, p. 124)
} 
nesa chamada Empório Celestial de Conhecimentos Benévolos. $\mathrm{E}$ a terceira $\sqrt{8}$ se refere às mil subdivisões utilizadas pelo Instituto Bibliográfico de Bruxelas para classificar o universo.

A partir destes três exemplos, Borges conclui que as classificações são arbitrárias e conjecturais pelo simples fato de que não sabemos o que é isso que se está tentando classificar 9 . Foucault arrisca o palpite de que o único lugar onde poderiam se avizinhar itens aparentemente tão incompatíveis quanto os mostrados por Borges seria o espaço próprio da linguagem:

[...] onde poderiam eles jamais se encontrar, a não ser na voz imaterial que pronuncia sua enumeração, a não ser na página que a transcreve? Onde poderiam eles se justapor, senão no não lugar da linguagem? (FOUCAULT, 2010a, p. X)

Questiona assim sobre o solo a partir do qual se pretende a co- erência das classificações, esboçando certa suspeita sobre as relações entre linguagem e verdade:

Quando instauramos uma classificação refletida, quando dizemos que o gato e o cão se parecem menos que dois galgos, mesmo se ambos estão adestrados ou embalsamados, mesmo se os dois correm como loucos e mesmo se acabam de quebrar a bilha, qual é, pois, o solo a partir do qual podemos estabelecê-lo com inteira certeza? Em que 'tábua', segundo qual espaço de identidades, de similitudes, de analogias, adquirimos o hábito de distribuir tantas coisas diferentes e parecidas? Que coerência é essa - que se vê logo não ser nem determinada por um encadeamento a priori e necessário, nem imposta por conteúdos imediatamente sensíveis? (FOUCAULT, 2010a, p. XIV)

\footnotetext{
8 "O Instituto Bibliográfico de Bruxelas também pratica o caos: parcelou o universo em mil subdivisões, das quais a 262 corresponde ao papa; a 268 às escolas dominicais; a 298, ao mormonismo, e a 294, ao bramanismo, budismo, xintoísmo e taoísmo. Não recusa as subdivisões heterogêneas, verbi gratia, a 179: 'Crueldade com os animais. Proteção dos animais. O duelo e o suicídio do ponto de vista moral. Vícios e defeitos variados. Virtudes e qualidades variadas." (BORGES, 2007a, p. 124)

9 "[...] sabidamente não há classificação do universo que não seja arbitrária e conjectural. A razão é muito simples: não sabemos o que é o universo. [...] É possível ir mais longe; é possível suspeitar de que não haja universo no sentido orgânico, unificador, que tem essa ambiciosa palavra." (BORGES, 2007a, pp. 124-125)
} 
As menções a Borges também aparecem em um texto publicado por Foucault em 1963 chamado A linguagem ao Infinito (2009). Aqui, a referência é A biblioteca de Babel (2007). Neste conto, Borges fala de um universo que seria organizado como uma biblioteca talvez infinita ${ }^{10}$, Nesta biblioteca, tudo o que pode ser escrito já foi escrito 11 . E mesmo nessa infinidade de livros escritos, entretanto, algumas coisas seriam muito difíceis de ser encontradas, como as verdades ${ }^{12}$ ou os disparates ${ }^{13}$.

Foucault estava atento ao mero acaso que seria encontrar qualquer coerência formal diante da infinitude da biblioteca:

Em La bibliothèque de $\mathrm{Ba}$ bel, tudo o que pode ser dito já foi dito: é possível encontrar ali todas as linguagens concebidas, imaginadas, e mesmo as concebíveis, imagináveis; tudo foi pronunciado, mesmo o que não tem sentido, a tal ponto que a descoberta da mais fina coerência formal é um acaso altamente improvável, do qual muitas das existências, embora obstinadas, jamais receberam o favor. (FOUCAULT, 2009, pp. 57-58)

E afirma ainda que o espaço da linguagem funciona hoje como a biblioteca descrita por Borges:

Hoje, o espaço da linguagem não é definido pela Retórica, mas pela Biblioteca: pela sustentação ao infinito das linguagens fragmentares, substituindo à dupla cadeia

\footnotetext{
10 "O universo (que outros chamam a Biblioteca) compõe-se de um número indefinido, e talvez infinito, de galerias hexagonais, com vastos poços de ventilação no centro, cercados por balaustradas baixíssimas.” (BORGES, 2007, p .69)

11 "Tudo: a história minuciosa do futuro, as autobiografias dos arcanjos, o catálogo fiel da Biblioteca, milhares e milhares de catálogos falsos, a demonstração da falácia desses catálogos, a demonstração da falácia do catálogo verdadeiro, o evangelho gnóstico de Basilides, o comentário desse evangelho, o comentário do comentário desse evangelho, o relato verídico de tua morte, a versão de cada livro em todas as línguas, as interpolações de cada livro em todos os livros; o tratado que Beda pôde escrever (e não escreveu) sobre a mitologia dos saxões, os livros perdidos de Tácito.” (BORGES, 2007, p. 73)

12 "Sei de uma região montanhosa cujos bibliotecários repudiam o supersticioso e vão costume de procurar sentido nos livros e o equiparam ao de procurá-lo nos sonhos ou nas linhas caóticas da mão... Admitem que os inventores da escrita imitaram os vinte e cinco símbolos naturais, mas sustentam que essa aplicação é casual, e que os livros em si nada significam." (BORGES, 2007, p. 72)

13 "De fato, a Biblioteca inclui todas as estruturas verbais, todas as variantes que permitem os vinte e cinco símbolos ortográficos, porém nem um único disparate absoluto. Inútil observar que o melhor volume dos muitos hexágonos que administro intitula-se Trovão Penteado, e outro A Cãibra de Gesso e outro Axaxaxas mlö. Essas proposições, à primeira vista incoerentes, sem dúvida são passíveis de uma justificativa criptográfica ou alegórica [...]." (BORGES, 2007, p. 77)
} 
da retórica a linha simples, contínua, monótona de uma linguagem entregue a si mesma, devotada a ser infinita porque não pode mais se apoiar na palavra do infinito. (FOUCAULT, 2009, p. 58)

Curiosamente, no final de $A B i$ blioteca de Babel, o bibliotecário que narra o conto de Borges revela sua suspeita de que talvez o homem vá sumir diante da infinitude da biblioteca ${ }^{14}$. Aqui é inevitável a comparação com a polêmica morte do homem, especulada por Foucault no fim de As palavras e as coisas:

O homem é uma invenção cuja recente data a arqueologia de nosso pensamento mostra facilmente. E talvez o fim próximo. (FOUCAULT, 2010a, p. 535)

É possível, então, arriscar dizer que o livro As palavras e as coisas não apenas começa com Borges, mas que também termina com ele. Não somente por causa dessa coincidência da suspeita do fim do homem diante do infinito da linguagem, mas também por um detalhe aparentemente inocente e talvez cuidadosamente inserido por Foucault no fim deste livro. O livro de areia (BORGES, 2009) é um conto onde um bibliotecário aposentado fala de um vendedor que a pareceu em sua casa para lhe oferecer um livro que possuía infinitas páginas 15 . Talvez inspirado por O livro de areia, Foucault termina As Palavras e as coisas assim:

[...] então se pode apostar que o homem se desvaneceria, como, na orla do mar, um rosto de areia. (FOUCAULT, 2010a, p. 535)

Como na Biblioteca de Babel, o infinito surge em O livro de areia para apagar os sistemas de referências.

\footnotetext{
14“A escrita metódica distrai-me da presente condição dos homens. A certeza de que tudo está escrito nos anula ou nos fantasmagoriza. [...] Talvez me enganem a velhice e o temor, mas suspeito que a espécie humana - a única está por extinguir-se e que a Biblioteca perdurará: iluminada, solitária, infinita, perfeitamente imóvel, armada de volumes preciosos, inútil, incorruptível, secreta." (BORGES, 2007, p. 78)

$15 "$ - Não pode ser, mas é. O número de páginas deste livro é exatamente infinito. Nenhuma é a primeira; nenhuma é a última. Não sei por que são numeradas desse modo arbitrário. Talvez para dar a entender que os termos de uma série infinita admitem qualquer número.

Depois, como se pensasse em voz alta:

- Se o espaço for infinito, estamos em qualquer ponto do espaço. Se o tempo for infinito, estamos em qualquer ponto do tempo.

Suas considerações irritaram-me."

(BORGES, 2009, pp. 102-103)
} 
Como se pode estar em um ponto do espaço ou do tempo se eles são infinitos? Como se pode ter lugar na linguagem se ela é infinita? As considerações que irritaram o bibliotecário aposentado de Borges parecem ser as mesmas que provocaram o riso de Foucault, mas que também o fizeram concordar com Borges, não só sobre o desvanecimento do homem, mas talvez sobre a impossibilidade de existir na infinitude da linguagem qualquer sistema de referências absoluto, inclusive, ou, especialmente, a verdade:

Assim, a impossibilidade de a linguagem dizer qualquer coisa sobre o real que não seja ficção constitui nos contos de Borges um enigma em torno do duplo caráter da linguagem no qual a Biblioteca e o Livro de Areia são duas partes complementares como o finito e o infinito, a permanência e o devir que o torna possível na sua impossibilidade. (MENEZES, 2008, p. 26)

Após ler As palavras e as coisas, René Magritte envia em 1966 uma carta a Foucault fazendo considerações sobre dois termos privilegiados por Foucault neste li- vro, quais sejam, similitude e semelhança:
As 'coisas' não possuem entre si semelhanças, elas têm ou não têm similitu- des. Só ao pensamento é dado ser semelhante. (MAGRITTE, 2014, p. 75)

Magritte anexa em sua carta algumas reproduções de quadros seus, incluindo aí Les Deux mystères, obra que faz parte da série de quadros conhecida como Ceci n'est pas une pipe. Foucault faz então uma análise sobre esse quadro e a publica em 1973 como Isto não é um cachimbo (2014a).

O quadro de Magritte parece ter feito Foucault refletir não apenas sobre o espaço infinito da linguagem e as suas arbitrariedades, algumas delas trazidas à tona por Borges, mas também sobre as diabruras que o mais simples emprego de similitudes é capaz de produzir:

[...] há dois cachimbos. Não seria necessário dizer, em vez disso: dois desenhos de um mesmo cachimbo? Ou ainda um cachimbo e seu desenho, ou ainda dois desenhos representando cada um deles um cachimbo, ou 
ainda dois desenhos dos quais um representa um cachimbo, mas o outro não, ou ainda dois desenhos que nem um nem outro são ou representam cachimbos, ou ainda um desenho representando não um cachimbo, mas um outro desenho que, ele, representa um cachimbo [...]. (FOUCAULT, 2014a, pp. 16-17)

'Isso não é um cachimbo, mas o desenho de um cachimbo', 'Isto não é um cachimbo, mas uma frase dizendo que é um cachimbo', 'a frase: < Isso não é um cachimbo> não é um cachimbo'; 'na frase: <Isso não é um cachimbo >, <isto> não é um cachimbo: este quadro, esta frase escrita, este desenho de um cachimbo, tudo isso não é um cachimbo'. As negações se multiplicam, a voz se embrulha e engasga [...]. (FOUCAULT, 2014a, p. 36)

A confusão toda acontece apesar de, simplesmente, ou obviamente, não haver cachimbo algum:

Em nenhum lugar há ca- chimbo.

(FOUCAULT, 2014a, p. 34)

Ou seja, não há coisas. Só palavras e desenhos. Ou apenas desenhos. Desenhos de coisas e de palavras. Ou nem mesmo isso. Talvez haja apenas um mero jogo de similitudes:

Magritte liga os signos verbais e os elementos plásticos, mas sem se outorgar, previamente, uma isotopia; esquiva o fundo de discurso afirmativo, sobre o qual repousava tranquilamente a semelhança: e coloca em jogo puras similitudes e enunciados verbais não afirmativos, na instabilidade de um volume sem referência e de um espaço sem plano. (FOUCAULT, 2014a, pp. 71-72)

O resto é produto da semelhança, dada apenas ao pensamento, como já havia alertado Magritte a Foucault, que acaba concluindo que "pintar não é afirmar", expressão que usa para dar nome à seção de conclusão do seu artigo sobre a travessura de Magritte.

Mas se pintar não é afirmar, escrever o é? Em um texto publicado em 1963, chamado Distância, 
Aspecto, Origem (2009a), Foucault analisa o estatuto da linguagem a partir da obra de Alain RobbeGrillet, escritor e cineasta francês. Aqui, Foucault fala de uma distância que se abre quando se escreve:

[...] a simples experiência que consiste em pegar uma caneta e escrever franqueia [...] uma distância que não pertence nem ao mundo, nem ao inconsciente, nem ao olhar, nem à interioridade [...] (FOUCAULT, 2009a, p. 69)

Essa distância é precisamente o que Foucault chama de ficção. Para ele, ficção não é o que acontece quando as palavras estão distantes das coisas, quando não as descrevem em sua realidade, quando as faz parecer algo que não são. Ficção é, para Foucault, a própria descrição das coisas:

[...] o fictício é um afastamento próprio da linguagem - um afastamento que tem nela seu lugar, mas que também a expõe, dispersa, reparte, abre. Não há ficção porque a linguagem está distante das coisas; mas a linguagem é sua distância [...] (FOU-

CAULT, 2009a, p. 69)

Para deixar claro que sua noção de ficção não está associada ao irreal, Foucault simula uma aproximação com o pensamento surrealista, apenas para se afastar dele logo em seguida. Primeiro questiona se não seria o caso de a ficção corresponder àquelas experiências fora da realidade trazidas à tona por meio da linguagem do surrealismo:

Atravessando, de viés, a incerteza do sonho e da espera, da loucura e da vigília, a ficção não designa uma série de experiências às quais o surrealismo já havia emprestado sua linguagem? (FOUCAULT, 2009a, p. 68)

Em seguida, Foucault se afasta desta ideia, propondo que tais experiências de ficção seriam as experiências mesmas que vivenciamos, posicionadas em um solo que é uma ausência de solo:

Mas e se essas experiências, pelo contrário, pudessem ser mantidas onde estão, em sua superfície sem profundidade, nesse 
volume impreciso de onde elas nos vêm, vibrando em torno do seu núcleo indeterminável, sobre seu solo que é uma ausência de solo? E se o sonho, a loucura, a noite não marcassem o posicionamento de nenhum limiar solene, mas traçassem e apagassem incessantemente os limites que a vigília e o discurso transpõem, quando eles vêm até nós e nos chegam já desdobrados? (FOUCAULT, 2009a, p. 68)

Foucault volta a falar em ficção em $O$ pensamento do exterior (2009b), artigo sobre o escritor francês Maurice Blanchot publicado em 1966. Em um trecho confuso, Foucault tenta mostrar novamente a impossibilidade de que a linguagem não produza um afastamento entre o falado e o visível:

O fictício não está nunca nas coisas nem nos homens, mas na impossível verossimilhança do que está entre eles: encontros, proximidade do mais longínquo, absoluta dissimulação lá onde nós estamos. A ficção consiste, portanto, não em mostrar o invisível, mas em mostrar o quanto é invisível a invisibilidade do visível. (FOUCAULT, 2009b, p. 225)

Foucault também chama atenção para a diferença entre o ser da linguagem e o ser do cogito. A diferença fundamental é que o ser do cogito traz a certeza da existência do $E u$, ao contrário do ser da linguagem, que apaga essa existência:

Ora, o que torna tão necessário pensar essa ficção - enquanto antigamente se tratava de pensar a verdade - é que o 'eu falo' funciona ao contrário do 'eu penso'. Este conduzia de fato a certeza indubitável do Eu e de sua existência; aquele, pelo contrário, recua, dispersa, apaga essa existência e dela só deixa aparecer o lugar vazio. (FOUCAULT, 2009b, p. 221)

O apagamento do $E u$ se dá pela natureza ilimitada da linguagem, sem qualquer restrição em relação à verdade, aos valores, aos sistemas representativos: 
[...] nada pode limitá-la nem aquele a quem ela se dirige, nem a verdade do que ela diz, nem os valores ou os sistemas representativos que ela utiliza; em suma, não é mais discurso e comunicação de um sentido, mas exposição da linguagem em seu ser bruto, pura exterioridade manifesta [...] (FOUCAULT, 2009b, p. 220)

Eis, portanto, uma possível leitura, ainda que não exaustiva, sobre as noções de linguagem e de verdade em Foucault. Uma linguagem infinita, que apaga os sistemas de referência, que não tem na verdade sua norma, que faz desvanecer o homem, que franqueia uma distância, que implica em ficção, não pela distância entre as palavras e as coisas, mas uma ficção que seria um afastamento próprio da linguagem.

Noções estas que talvez estejam presentes em toda a obra de Foucault, constituindo-se, possivelmente, sem prejuízo de outros, como um elemento de continui- dade entre as suas diferentes fases ${ }^{16}$. No prefácio do segundo volume de A história da sexualidade, obra relacionada à sua última fase, Foucault sugere essa continuidade ao retomar objetos clássicos de seus primeiros livros e os relacionar a jogos de verdade:
"Através de quais jogos de verdade o homem se dá seu ser próprio a pensar quando se percebe como louco, quando se olha como doente, quando se reflete sobre si como ser vivo, ser falante e ser tra- balhador, quando ele se julga e se pune enquanto criminoso? Através de quais jogos de verdade o ser humano se reconheceu como homem de desejo?" (FOUCAULT, 1998, p. 12)

Em uma entrevista de 1984, ano de sua morte, Foucault deixa claro que seu problema sempre teria sido a relação entre o sujeito e a verdade:

\footnotetext{
${ }^{16}$ Convencionalmente, a obra de Foucault é dividida em três fases. Inicialmente, ele estaria mais focado na formação dos discursos, dos objetos, dos conceitos, das estratégias, toda uma arqueologia do saber. Situam-se nessa fase os livros A história da loucura (1961), O nascimento da clínica (1977), As palavras e as coisas (2010a) e A arqueologia do saber (2008). Em seguida, Foucault passa a examinar diferentes tipos de poder exercidos a partir dos saberes, como o poder disciplinar, o poder pastoral e o biopoder, uma genealogia do poder, portanto. Aqui se encaixariam o livro Vigiar e Punir (2014c) e o curso Nascimento da Biopolítica (2008a), dentre outras publicações. Por fim, há a análise das formas de subjetivação pelas quais os indivíduos se reconhecem como sujeitos, onde estariam situados todos os volumes da série A história da sexualidade.
} 
"Meu problema sempre foi, como dizia no início, o das relações entre sujeito e verdade: como o sujeito entra em um certo jogo de verdade." (FOUCAULT, 2004, p. 274)

"Assim, fui levado a colocar o problema saber/poder, que é para mim não o problema fundamental, mas um instrumento que permite analisar, da maneira que me parece mais exata, o problema das relações entre sujeito e jogos de verdade." (FOUCAULT, 2004, p. 274)

Por fim, é importante frisar que Foucault não parece ver problema algum em situar em sua própria obra a natureza fictícia da linguagem. Quando questionado sobre a verdade contida em suas análises, confessa, talvez um pouco sarcasticamente, que o que escreve não passa de ficção:

Pratico uma espécie de ficção histórica. De certa maneira, sei muito bem que aquilo que digo não é verdade. (FOUCAULT, 2006, p. 321)

[...] as pessoas que me leem, em particular aquelas que apreciam o que faço, dizem-me, frequentemente, rindo: 'No fundo, você sabe bem que o que diz não passa de ficção.' E respondo sempre: 'Certamente, não se trata de questão que seja outra coisa senão ficções.' (FOUCAULT, 2010b, p. 292)

É possível especular que essas confissões talvez sejam provocações. No fundo, não seriam meras confissões. Seriam, também, e principalmente, acusações. A ficção é um afastamento próprio da linguagem. Não só da linguagem de Foucault, mas de toda linguagem. Seriam provocações que carregariam toda a essência de sua obra, portanto. E seriam, como quis Bourdieu, desconstruções que de forma alguma se esqueceram de desconstruir o próprio desconstrutor.

\section{Conclusão}

Até aqui, procurou-se levantar algumas dificuldades que surgem ao se assumir para Foucault um lugar fixo de fala, especialmente quando se leva em consideração as suas próprias noções de linguagem e de verdade. Nesta última seção, busca-se concluir o trabalho 
mostrando como essas noções parecem ter inspirado em Foucault certas práticas de si que privilegiam o deslocamento.

Nos últimos anos de sua carreira, ao se voltar para o tema mais geral da ética em seus livros sobre a sexualidade, Foucault falava constantemente sobre uma ética da vida como obra de arte, sobre toda uma estética da existência:

Esta elaboração da própria vida como uma obra de arte pessoal, ainda que obedecendo certos cânones coletivos, estava ao centro, me parece, da experiência moral, da vontade moral na Antiguidade $[\ldots]$ (FOUCAULT, 1984b, p. 2)

Em uma entrevista de 1978, Foucault revela como buscou praticar a si mesmo, experimentar a si mesmo, transformar a si mesmo, imprimindo, de certa forma, uma estética à sua obra e à sua existência:

Quando começo um livro, não somente não sei o que pensarei no final, mas não sei, claramente, que método empregarei. Cada um de meus livros é uma maneira de recortar um objeto e de forjar um método de análise. (FOUCAULT, 2010b, p. 290)

Meu problema era de fazer eu mesmo, e de convidar os outros a fazerem comigo, através de um conteúdo histórico determinado, uma experiência do que somos, do que é não apenas nosso passado, mas também nosso presente, uma experiência de nossa modernidade de tal forma que saíssemos transformados. (FOUCAULT, 2010b, p. 292)

Foucault fala em livros-experiência para posicionar seus próprios livros em oposição ao que seriam os livros-verdade ou os livrosdemonstração:

Um livro sistemático que empregasse um método generalizável ou que desse demonstração de uma teoria traria ensinamentos. Meus livros não têm, exatamente, esse valor. São, antes, convites, gestos feitos em público. (FOUCAULT, 2010b, p. 295)

Eis o que é, para mim, um livro-experiência, em oposição a um livroverdade e a um livro- 
demonstração.

(FOU-

CAULT, 2010b, p. 296)

E comenta sobre o estatuto da verdade nesses livros-experiência, que, como já era de se esperar, é inexistente, não na forma de uma ausência, mas na forma própria de uma norma:

Ora, essa experiência não é nem verdadeira nem falsa. Uma experiência é sempre uma ficção; é alguma coisa que se fabrica para si mesmo, que não existe antes e que poderá existir depois. (FOUCAULT, 2010b, p. 293)

Escrever para transformar a si mesmo, eis, portanto, uma prática de si adotada por Foucault. Mas há outras. Em O que é a Crítica (1990), por exemplo, Foucault fala também em escrever contra toda uma politica da verdade:

E se a governamentalização é mesmo esse movimento pelo qual se tratasse na realidade mesma de uma prática social de sujeitar os indivíduos por mecanismos de poder que reclamam de uma verdade, pois bem, eu diria que a crítica é o movimento pelo qual o sujeito se dá o direito de interrogar a verdade sobre seus efeitos de poder e o poder sobre seus discursos de verdade; pois bem, a crítica será a arte da inservidão voluntária, aquela da indocilidade refletida. A crítica teria essencialmente por função a desassujeitamento no jogo do que se poderia chamar, em uma palavra, a política da verdade. (FOUCAULT, 1990, p. 5)

Outra prática de si, então, essa crítica como interrogação tanto da verdade sobre seus efeitos de poder quanto do poder sobre seus discursos de verdade. Em O que é o Iluminismo (1984), defende não uma analítica da verdade, mas uma analítica do presente:

'O que é nossa atualidade? Qual é o campo atual das experiências possíveis?'. Não se trata de uma analítica da verdade, consistiria em algo que se poderia chamar de analítica do presente, uma ontologia de nós mesmos [...] (FOUCAULT, 1984, p. 8)

[...] pode-se optar por 
uma filosofia crítica que se apresenta como uma filosofia analítica da verdade em geral, ou bem se pode optar por um pensamento crítico que toma a forma de uma ontologia de nós mesmos, de uma ontologia da atualidade, é esta forma de filosofia que de Hegel à Escola de Frankfurt, passando por Nietzsche e Max Weber, fundou uma forma de reflexão na qual tenho tentado trabalhar. (FOUCAULT, 1984, p. 9)

Mais uma prática de si, portanto, a analítica do presente, essa ontologia de nós mesmos, uma ontologia da atualidade. Em uma entrevista de 1979, Foucault fala ainda em escrever para transformar o presente:

Procuro provocar uma interferência entre nossa realidade e o que sabemos de nossa história passada. Se tenho sucesso, essa interferência produzirá reais efeitos em nossa história presente. Minha esperança é que meus livros tomem a sua verdade uma vez escritos, e não antes. (FOUCAULT, 2006, p.
321)

[...] há dois anos, na França, houve agitação em várias prisões, os detentos se revoltaram. Em duas dessas prisões os prisioneiros liam meu livro. De suas celas, alguns detentos gritavam o texto de meu livro para seus companheiros. Sei que o que direi é pretensioso, mas é uma prova de verdade de verdade política, tangível, uma verdade que começou uma vez escrito o livro. Espero que a verdade de meus livros esteja no futuro. (FOUCAULT, 2006, p. 322)

Escrever para transformar a si mesmo, escrever contra a política da verdade, escrever sobre o presente, e escrever para mudar a história do presente. Práticas de si que, isoladas, talvez não provocassem particularmente nenhum alarde, mas que, ao serem empregadas simultaneamente, como no caso de Foucault, tornam seu trabalho particularmente difícil de analisar, de sistematizar, de interpretar, de enquadrar. O deslocamento parece ser a regra. Nada que ele mesmo não nos tivesse alertado ainda em 1969, no prefácio de $A$ arqueologia do saber: 
Não me pergunte quem sou e não me diga para permanecer o mesmo. (FOUCAULT, 2008, p. 20)

Nesta mesma época, em 1971, Foucault proferiu na Tunísia uma conferência sobre a pintura de Manet, na qual ele destacou, entre outros aspectos, a técnica por meio da qual Manet faz deslocar os lugares do pintor e do espectador no quadro Un bar aux FoliesBergère:

[...] não é possível saber onde se encontrava o pintor para pintar o quadro como ele o fez, e onde nós deveríamos nos posicionar para ver um espetáculo como esse. E vocês veem que então, com essa última técnica, Manet faz agir a propriedade do quadro de não ser, de modo algum, um espaço de certa forma normativo, cuja representação nos fixa ou fixa ao espectador um ponto $\mathrm{e}$ um ponto único de onde olhar, o quadro aparece como um espaço à frente do qual e em relação ao qual podemos nos deslocar [...]. (FOUCAULT, 2010, p. 283)

Tentava Foucault fazer algo assim em sua obra? Na já mencionada entrevista de 1978, ele sugere que sim:

Tenho absoluta consciência de me deslocar sempre, ao mesmo tempo, em relação às coisas pelas quais me interesso e em relação ao que já pensei. (FOUCAULT, 2010b, p. 289)

Não é trivial, portanto, posicionarse em relação a Foucault, muito menos saber a partir de onde ele fala. Para ele, sistema de referências nenhum alcança a "vontade de verdade" (FOUCAULT, 2014, p. 19) quando confrontado com a infinitude da linguagem. Saber nenhum, sujeito nenhum, poder nenhum. Diante dessa infinitude, resta para ele como possibilidade apenas a "coragem da verdade" (FOUCAULT, 2011), ou seja, viver a vida a partir de experiências de si mesmo. Foucault parece tentar fazer justamente isso ao se deslocar o tempo todo, e talvez nos convide também a fazer o mesmo. 


\section{Referências}

BORGES, Jorge Luis. A biblioteca de Babel. In: Ficções. São Paulo: Companhia das Letras, 2007.

. O idioma analítico de John Wilkins. In: Outras Inquisições. São Paulo: Companhia das Letras, 2007a.

. O livro de areia. In: O livro de areia. São Paulo: Companhia das Letras, 2009.

BOURDIEU, Pierre. Os fundamentos históricos da razão. In: Meditações pascalianas. Rio de Janeiro: Bertrand Brasil, 2001, pp. 113-156.

DERRIDA, Jacques. Cogito e a história da loucura. In: A escritura e a diferença. $4^{\text {a }}$ ed. São Paulo: Perspectiva, 2009.

FOUCAULT, Michel. Folie et Déraison. Paris: Plon, 1961.

. O nascimento da clínica. Rio de Janeiro: Forense Universitária, 1977.

. O que é o Iluminismo? Magazine Littéraire, no 207, 1984, pp. 3539. (Original de 1983, tradução para o português por wanderson flor do nascimento, disponível em $<$ http://michel-foucault.weebly.com/>)

- Uma estética da existência. Le Monde, 15 de julho de 1984b. (Tradução para o português por wanderson flor do nascimento, disponível em $<$ http://michel-foucault.weebly.com/>)

Além das fronteiras da filosofia. Le Monde, 6 de setembro de 1986. (Original de 1975, tradução para o português por wanderson flor do nascimento, disponível em

$<$ http://michel-foucault.weebly.com/>)

- O que é a crítica? Bulletin de la Société Française de Philosophie, Vol. 82, no 2, 1990, pp. 35-63. (Original de 1978, tradução para o português por wanderson flor do nascimento, disponível em <http://michel-foucault.weebly.com/>)

- Nietzsche, Freud e Marx. São Paulo: Princípio Editora, 1997. (Original de 1975)

- História da Sexualidade 2: o uso dos prazeres. $8^{\mathrm{a}}$ ed. Rio de Janeiro: Edições Graal, 1998. (Original de 1984)

. A Ética do Cuidado de Si como Prática da Liberdade. In: MOTTA, Manuel Barros da (Org.). Ditos e Escritos (Vol. V). Rio de Janeiro: Forense Universitária, 2004, pp. 264-287. (Original de 1984) 
. Estruturalismo e Pós-estruturalismo. In: MOTTA, Manuel Barros da (Org.). Ditos e Escritos (Vol. II). Rio de Janeiro: Forense Universitária, 2005, pp. 307-334. (Original de 1983)

- Foucault estuda a Razão de Estado. In: MOTTA, Manuel Barros da (Org.). Ditos e Escritos (Vol. IV). Rio de Janeiro: Forense Universitária, 2006, pp. 317-322. (Original de 1979)

. A arqueologia do saber. $7^{\mathrm{a}}$ ed. Rio de Janeiro: Forense Universitária, 2008.

. Nascimento da Biopolítica. São Paulo: Martins Fontes, 2008a.

. A Linguagem ao Infinito In: MOTTA, Manuel Barros da (Org.). Ditos e Escritos (Vol. III). Rio de Janeiro: Forense Universitária, 2009, pp. 47-59. (Original de 1963)

- Distância, Aspecto, Origem. In: MOTTA, Manuel Barros da (Org.). Ditos e Escritos (Vol. III). Rio de Janeiro: Forense Universitária, 2009a, pp. 60-74. (Original de 1963)

. O pensamento do exterior. In: MOTTA, Manuel Barros da (Org.). Ditos e Escritos (Vol. III). Rio de Janeiro: Forense Universitária, 2009b, pp. 219-242. (Original de 1966)

A pintura de Manet. Visualidades. Vol. 8, n. 2, pp. 259-285, 2010. (Original de 1971, tradução para o português por Rodolfo Eduardo Scachetti) . As palavras e as coisas. São Paulo: Martins Fontes, 2010a.

- Conversa com Michel Foucault. In: MOTTA, Manuel Barros da (Org.). Ditos e Escritos (Vol. VI). Rio de Janeiro: Forense Universitária, 2010b, pp. 289-347. (Original de 1978) - A coragem da verdade. São Paulo: Martins Fontes, 2011.

- A ordem do discurso. São Paulo: Loyola, 2014.

. Isso não é um cachimbo. São Paulo: Paz e Terra, 2014a.

. Que é o senhor, professor Foucault? In: Ditos e Escritos (Vol. X). Rio de Janeiro: Forense Universitária, 2014b, pp. 29-49.

. Vigiar e punir. Petrópolis: Vozes, 2014c.

GINZBURG, Carlo. Descobertas de um espectador. São Paulo: Folha, 1999. (Entrevista concedida a Maria Lúcia G. Pallares-Burke em 13/06/1999, disponível em

<http://www1.folha.uol.com.br/fsp/mais/fs13069912.htm>)

HABERMAS, Jürgen. O discurso filosófico da modernidade: doze lições. São Paulo: Martins Fontes, 2000.

LYOTARD, Jean-François. A condição pós-moderna. $12^{\mathrm{a}}$ ed. Rio de Janeiro: José Olympio, 2009. 
MAGRITTE, René. Duas cartas de René Magritte. In: FOUCAULT, Michel. Isso não é um cachimbo. São Paulo: Paz e Terra, 2014, pp. 75-78.

MENEZES, Antônio B. N. T. Foucault, Borges e a experiência da linguagem. Saberes. Vol. 1, n. 1, 2008.

Recebido: $18 / 02 / 2019$

Aprovado: $15 / 04 / 2019$

Publicado: 13/05/2019 